\title{
ПОХИЛ С.І. БАБЕЗІОЗ : КОЛЕКТИВНА МОНОГРАФІЯ / С.І. ПОХИЛ, К.І. БОДНЯ, І.І. ТОРЯНИК ТА ІН. - Х. : ФОП БРОВІН О.В., 2018. - 204 с.
}

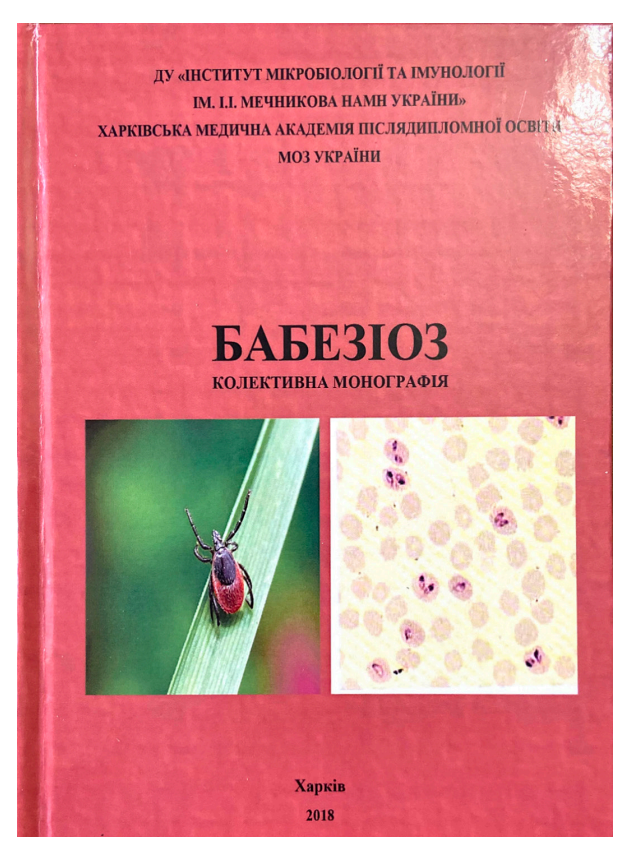

У колективній монографії відомих науковців узагальнено сучасні досягнення у вивченні бабезіозу людини кров'яної інфрекції, яку спричиняють найпростіші з роду Babesia. Доцільність видати книжку була продиктована значним розповсюдженням цієї хвороби серед людей і тварин та зв'язаними 3 нею медичними й соціально-економічними збитками. Водночас медичні працівники натепер слабо поінформовані про ризики зараження бабезіозом, його клінічні прояви, діагностику, лікування та просрілактику.

Монографрія складена з двох частин. У першій, яка ґрунтується на даних літератури, детально описано сучасну класифрікацію бабезіозу, біологічні властивості та життєвий цикл найпростіших гемопаразитів з роду Babesia. Чільне місце відведено висвітленню епідеміології цього гемопаразитозу та особливостей формування імунітету. Детально описано клінічні прояви бабезіозу в людей 3 врахуванням тяжкості інфекційного процесу, особливості гострих і хронічних фрорм.
Наведено епідеміологічні, клінічні та лабораторні критерії діагностики, останні поділені на безумовні та ймовірні. Послідовно розглянуто мікроскопічні, молекулярно-генетичні, культуральні та біологічні методи діагностики, їх чутливість і специорічність, переваги та недоліки. Справедливо зазначено, що специфрічна діагностика потребує вдосконалення.

Перечислено основні етіотропні хіміопрепарати (атоваквон у поєднанні з азитроміцином та кліндаміцин сумісно з хініном), режим дозування і тривалість курсів лікування, можливі побічні реакції та ускладнення. Вказано перспективу апробації сполук хінолінів, подібних до ендохіну, та препарату ELQ-334 поєднано з атоваквоном, а також нових протималярійних препаратів.

Вказано основні напрямки профрілактики захворювань на бабезіоз у людей: ерадикація тварин, які слугують резервуаром збудників зооантропонозного бабезіозу, уникнення особами з групи ризику перебування в ендемічних/ ензоотичних щодо бабезіозу регіонах у сезони пікової активності кліщів та дотримання «розумної поведінки» у таких зонах; акарицидні заходи; застосування індивідуальних засобів захисту від кліщів; підвищення поінформованості населення і санітарна освіта.

У другій частині монографії висвітлено результати власних досліджень авторів щодо удосконалення методів лабораторної діагностики бабезіозу. Наведено конкретизовану характеристику нових методів, зокрема рівень їх новизни, технологічні особливості відтворення, переваги, показання до застосування, практичну доступність і місце використання. Запропоновано алгоритм застосування комплексу лабораторних методів розпізнання бабезіозу в людей, який відповідає теперішнім світовим вимогам. Автори вважають, що впровадження цього алгоритму в широку практику сприятиме підвищенню ефективності профрілактики і лікування бабезіозу в Україні.

На нашу думку, монографрія «Бабезіоз» становить значний інтерес для мікробіологів, паразитологів, епідеміологів, інфрекціоністів і працівників клініко-діагностичних лабораторій. Вона дає сучасне уявлення про проблему бабезіозу у людей, способи його виявлення, лікування та профрілактики. 


\section{РЕЦЕНЗІї}

\section{Відомості про автора:}

Андрейчин Михайло Антонович - доктор мед. наук, професор, академік НАМН України, зав. каф. інфекційних хвороб з епідеміологією, шкірними та венеричними хворобами ТНМУ імені І.Я. Горбачевського; e-mail: andreychyn@ tdmu.edu.ua;

ORCID ID: https://orcid.org/0000-0003-0154-730X
Information about the author:

Andreychyn M.A. - MD, Professor, Academician of the National Academy of Medical Sciences of Ukraine, Chief of the Department of Infectious Diseases with Epidemiology, Dermatology and Venereology, I. Horbachevsky Ternopil National Medical University; e-mail: andreychyn@tdmu.edu. ua;

ORCID ID: https://orcid.org/0000-0003-0154-730X

Конфрлікт інтересів: немає.

Author has no conflict of interest to declare.

Отримано 19.02.2020 р. 